\title{
Italy since the 1996 Elections: A Special Case with General Lessons
}

\section{COLIN CROUCH}

THE array of forces within Italian politics since the elections of April 1996 seems odd: a minority Government of reconstructed Communists, some Catholics and a few neo-liberals relies for support on a party of unreconstructed Communists and confronts an opposition coalition of postindustrial media people, financiers and superficially reconstructed fascists, plus some other Catholics and a large number of neo-liberals, while on the wings sit the northern separatists, the Lega Nord, representing some of the wealthiest and most modern regions of Europe by deploying medieval symbolism to define a territory that has no historical meaning.

Nevertheless, the Lega Nord apart, there is something prototypical and generalisable about this emerging pattern of alignments. The postwar pattern of Italian parties had collapsed spectacularly in the early 1990s, and although the reconstruction taking place is certainly not de nuovo-political alignments never are-Italians are enjoying an opportunity to shape their politics in more immediate response to contemporary pressures than are most other advanced democracies where past legacies are more enduring.

One must not exaggerate the scope for generalisation. There are very special features of the Italian case: almost unimaginably vast political corruption; divisions between north and south greater than those between many nations; and an oddly skewed modernisation. However, even on these points Italians seem to have suffered larger-than-life versions of more general malaises. True, in no other country has the leading national political figure of the postwar period been put on trial for suspected deep involvement with the world's largest and nastiest criminal organisation; but very few democracies have come through the past two decades without corruption scandals of some kind. Nothing in the advanced world can quite compare with the regional antagonisms between Italian southerners and northerners, who ostensibly share an ethnicity; but Belgium, Canada, Spain, the United Kingdom and now possibly Germany know something of the kind.

It is easy to be puzzled by a country which can lead the world in fashion and modern design but still find it impossible to run an efficient administrative system without recourse to forms of clientilism that ought not to have survived the nineteenth century. But is that so very much more comical than the nation that produced the first industrial revolution still having a largely hereditary parliamentary chamber and continuing to be obsessed with the matrimonial complications of its royal family?

Italian politicians share with those of virtually all other democracies at the present time a near-universal desire to square the circle of conceding more and more space to private forces and (wealthy) individuals while claiming to address certain major and urgent collective tasks. If there is anything interestingly unusual about Italy it is its need to address this common dilemma while 
confronting another, more local, one which also relates to the distinction between public and private but in a quite different way. I shall explore this particular dilemma before going on to examine how it interacts with the more general issue.

\section{The person and the community}

Let me risk an outrageous generalisation: in western Europe north of the Alps people tend to make a curious division between the way they act in private and among people known to them and the manner they adopt in less personal situations and more public spaces. The origins of the distinction probably lie in the strong (and sociologically dubious) emphasis on the separateness of the individual person from its social context developed by the Protestant faiths. The contrast is certainly most clearly observable in Scandinavia, Britain and northern Germany; but somehow it seems to have spread to much of urban France and other parts of non-Protestant northern Europe.

To continue to over-generalise, Italians rarely split their personalities in this way. Of course, they have a code of formal politeness for encountering strangers, just as do the British, Germans, Japanese and all other cultures which developed in times when modes of travel produced a much stronger distinction than exists today between those whom one met frequently and strangers. But in the everyday conduct of ordinary life little contrast is drawn by Italians between private and public behaviour. The ubiquitous telefonino, used for chatting loudly to family and friends wherever one happens to be-in a restaurant, at a football match or simply walking along a crowded street-is just the contribution of the 1990s to an existing rich tapestry of private life lived in public: the collective evening stroll of the passeggiata, large family meals in restaurants, the loud bubble of conversation in streets and buses, love-making on Roman park benches. And just as Italians will carry on their private lives in public, so they will conduct their public selves as though they were in private, even in the most formal roles. A police officer on duty who has just spotted a friend in a crowd, or who is feeling fed up and irritated, will show the appropriate feelings as demonstrably as if he were at home, with no concealment behind a passive mask of formality.

Italians prefer to act as though they were always in a community of people well known to them, where a past record of interpersonal trust and frequent gestures of friendliness make formal correctness unnecessary. This is the level at which Italian institutions work best: the networks of cooperative, highly efficient small firms, the daily life of a small town, local levels of organisations, religious and secular alike. This is community rooted in the personal-a very different and far less antagonistic juxtaposition from that between the collective and the individual with which political debate and large-scale institutions are concerned.

Difficulties appear when one tries to build from such a base to larger structures, trying to use the same techniques on a scale where the genuinely interpersonal becomes impossible: large firms, national political parties, levels of government bureaucracy from regional level upwards. Problems of coordination become severe, leading to inefficiencies. It is possible to dispense with formal rules and rely on personal encounter when doing business where trust can be monitored, but in an anonymous structure the same practice creates opportunities for corruption-especially when obligations to families and friends have complete priority over those to unknown strangers. At its best, the continuing personalism means that individuals working within large organisations will 
make a personal effort to find a way through the layers of incompetence. At its worst, the other side of the coin of personalism is the amorality of the anonymous: if you are not known to me, I have no means of relating to you, you have no claims on me and are entitled to no consideration from me. If one wants a reply to a letter from a public authority, or detailed consideration of a complex claim for a social security benefit, one had better develop some kind of special contact with someone in the organisation.

Thus a vicious spiral has set in. Over the decades national politicians and bureaucrats showed contempt for the anonymous masses and played the political game with their cliques with scant concern for the quality of the government services that were the ostensible reasons for their holding their positions. The citizens responded by further strengthening the quality of their local lives while reciprocating the contempt, ignoring the laws and tax demands of the anonymous authorities. They knew that if they needed something from a state agency it would be pointless to follow the rule book; they would have to develop some clientilistic relationships. They learned how to do this, but the mutual contempt was thereby only strengthened. Relations between authorities and citizens were anonymous and therefore amoral. Governments pretended to govern; taxpayers pretended to pay them taxes.

In such an environment strange things could develop. The Communist Party could generate its extraordinary reputation for good local government and encouragement of small-firm entrepreneurship, because its own anomalous combination of commitment to a strong local collectivity with defiance of the central state suited the Italian way of managing affairs in a way that, for example, could never be achieved by the attempted defiant municipal socialism of the British Labour left in the 1980s.

The only real losers were the popula- tion of the south, the Mezzogiorno, whose communities had been built around mobilising support for political bosses who promised to deliver subsidies from Rome, while communities in the centre and north of the country had turned their backs on Rome and set about their own, autonomous, development. The bosses took the money designated for helping the communities, but used it for private purposes or passed it on to the Mafia. The northern electorate became angry that it was paying taxes for projects that never happened. There was corruption in Milan as much as in Palermo, but at least there was something to show for it: underground railway lines were built and the airport extended. At Cataniasette in Sicily a new university for training health service and education administrators, built partly with European Union funds and opened by the Pope, has stood empty for the past three years because the money allocated to staff it and run courses somehow never reaches it.

The sheer success of the Italian economy during the 1980s exposed the contradictions of the model. The country had become richer than the UK, possibly even than France, but far from the modernisation transcending the problems, it exacerbated them: a bigger economy meant bigger corruption; much of the growth had been achieved by means of the local and personalist methods of the smallfirm networks rather than through a breakthrough to modern organisationand despite rather than with the help of national institutions. And since the client economy of the Mezzogiorno did not share in the benefits, the gap between it and the rest of the country grew wider.

As part of this crisis the corruption scandals, primarily affecting the Christian democratic and socialist parties but extending very widely in the political system, could be contained no longer. The crusading investigative magistrates of Mani pulite (Operation Clean Hands) 
made it clear that no one, however deeply entrenched in the overlapping power hierarchies of the national establishment and the Mafia, was beyond their reach. To what extent the bursting of the bubble was aided by the fact that, following the fall of the Soviet Union, the CIA no longer had any use for the Italian Mafia will eventually be revealed by historians.

In the wake of the collapse of the ruling coalition of Christian democrats, socialists and assorted insider small parties it had seemed that little could now prevent the former Communists in the Partito Democratico della Sinistra (PDS)-who were relatively untouched by national scandal, if only by virtue of having been in opposition since 1947-from forming a government. However, as is well known, the rapidly formed Forza Italia (FI) of Silvio Berlusconi and its subsequent alliance with both the extreme separatist and anti-south Lega Nord and the extreme integralist and southern post-fascist Alleanza Nazionale (AN) won the elections of 1994. This brand new coalition staggered on for a few months until the combination of its internal incoherence and the inevitable implication of Berlusconi's financial and entertainment empire in the corruption scandals brought it down. A technical, non-party government headed by Lamberto Dinia neo-liberal banker who had only been brought into active politics as a senior member of his government by Berlusconi himself-was able to govern the country effectively and fairly decisively with the support of PDS but with growing opposition from FI and AN until the 1996 elections brought the current coalition to power.

\section{The private and the public}

Italians therefore encounter the current universal struggle over the proper places of market and state, private and public, from a distinctive angle. Italian neo-lib- erals who are serious about proper public finances and not just intent on selling state enterprises to their friends and winning votes by cutting taxes know that a proper state capacity has to be established rather than demolished if this task is to be achieved. The dialectic of public and private is complex where public funds have for years been illegitimately channelled to private individuals. The Italian left has rarely shared the view of its colleagues elsewhere that a high level of public spending is an unequivocally positive indicator; they know where too much of the expenditure has gone. They know, too, that privatising state industries, while it diminished the scope for government command of the economy, also dissolved some of the patronage bases that had been used by their political opponents during their own long years of exclusion. The clash between local and central political authorities cannot be easily interpreted in terms of current rival orthodoxies, while the special Italian problem of the personal and the community does not correspond at all to the opposition between the individual and the collective, similar though they sound. It is not just that changing Italian preferred ways of doing business to the requirements of a large-scale modern society cuts right across that more familiar juxtaposition, but that there are some very healthy babies in the very dirty bathwater of Italian personalism that could easily be flushed away by unimaginative enthusiasts for administrative reform.

There is, therefore, much that is unique in the way that Italians must confront contemporary challenges; but in a curious way this very fact leads them to demonstrate certain more universal future possibilities. To demonstrate this we must return to the narrative. 


\section{The new shape of the centre- left}

The core of the parliamentary support of the Government of 1996 and its leading personnel are provided by the PDS, but the Prime Minister, Romano Prodi, is a former Christian democrat and a devout Catholic. In a sense the compromesso storico long advocated by the PDS's Communist predecessors has come to pass, but the actually existing compromesso differs considerably from the original conception. That conception had been based mainly on the premise that Christian democracy and Communism were the two hegemonic forces in Italy, and that the country could achieve decisive government only if they came together for at least a limited agenda. But the very party splits among both Christians and former Communists that had made the coalition possible left neither hegemonic.

Two rather contradictory forces have become more important than the original conception. Both socialist and Catholic traditions, in Italy and elsewhere, stand for the belief in and a commitment to the collective and the amendment of market forces in the interests of a more humane and less unequal society. It is at this point that the very special Italian search for a sense of the public good and for an effective national community intersects with something far more general, but cast in less polemical terms than that general debate and therefore more easily a subject for imaginative coalitionbuilding.

Seen in general terms, the Prodi Government is a social Christian coalition after the manner of Jacques Delors' European Commission, reminiscent of the alliance of social democrats and Christian democrats in the Commission and the Parliament that forged something of a European social agenda during the 1980s. It is the balance of forces which that wiliest of European politicians, Helmut Kohl, uses to keep the new
Germany together, without actually including the social democrats in government. It is the balance that more or less governs Belgium, the Netherlands and Austria, though not France since the sundering of the fortuitous cohabitation of a socialist President and a rightist administration.

It is an alliance that addresses the most fundamental issue of our age-how to construct a capacity for collective action in societies where individual advance and wealth accumulation seem so much easier to achieve if only collective responsibilities do not intrude-by bringing together two assertions of the priority of the collective. In the past they have presented bitterly rival visions, and their mutually inflicted wounds will not heal easily. They have also both become defensive visions, since they feed on past sources and experiences while the forces of unbridled market individualism are very contemporary. Finding its intellectual form though not its fundamental appetite in neo-liberalism, and its power centres in the world's financial centres and transnational corporations, this individualism constitutes a formidable challenge to however strong a pact Christian and social democracy might forge. It put an effective check on the development of Delors' European vision. And neo-liberalism is a major player in the new situation in Italy.

Alongside the PDS, the left Catholics and some tiny parties stand Dini and the small grouping he hurriedly formed around himself for the 1996 election and which supports the Government within which he is now the Foreign Minister. It is a distinctly neo-liberal set of bankers and others whose main concern is to clean up the Italian public finances, reduce public spending and prepare the country for European Monetary Union (EMU). Its relations with the PDS are far from easy and it is doubtful if that particular partnership has any long-term future, though without Dini and his 
group the Government would lose its majority. However, as explained above, an association of certain types of neoliberals and former Communists is less incongruous in Italy than in many other countries.

But even beyond that and the need for Dini's support, there would be neo-liberal elements to the Government's policies. In Italy, as everywhere else in the contemporary world of unrestrained capital movements and financial institutions capable of laying their hands on enormous sums of money, even only mildly left-of-centre politicians have to be very careful that the chance of their winning an election will not be greeted by a run on the currency and general financial chaos. It is probably not possible for the left-of-centre to govern anywhere today unless the wishes of the national democracy have the approval of the global plutocracy. Thus the PDS leader, Massimo d'Alema, and his colleagues were courting and reassuring the money men in the Piazza dei Affari in Rome as ardently as Tony Blair and Gordon Brown have been doing the same in the City of London, and well before they thought they might be in government alongside Lamberto Dini.

And so neo-liberal ideas, policies, groups have to be part of the 1990s version of the compromesso storico-even if the main centripetal force of the coalition is the defence of the collective to whose existence neo-liberalism constitutes the primary threat. Working a way through the paradox is far more challenging than the more obviously difficult task of reconciling the church and socialism. Every day, in everything the Government does, it has to find a way through this quagmire. Spending must be cut, but the welfare state must also be improved, not just protected, if the Government is to fulfil any of its hopes for securing change. Labour markets must be made more flexible, but the unions must not be dislodged from their place in Italian society. Gradually a pattern of deals and compromises emerges, though it has as yet no definable shape; and it could fall apart at any point if Rifondazione (the party of unreconstructed Communists which sustains the Government in parliament though not formally part of the majority) decided things had gone too far, or if the Dini group decided to mend fences with their more natural allies within Forza Italia.

What prevents any of this happening so far is that all parts of the governing coalition desperately want an Italy whose public institutions and finances are fit to qualify it for membership of the core group within the multi-track Europe which will emerge after the achievement of EMU. At present that core seems to comprise five of the six founding countries of the European Economic Community, plus Austria. Italy is losing its place, and that hurts. Even though it is sometimes said that the Bundesbank's real condition for monetary union is 'whatever terms Italy cannot make', Italy is determined to be there, even at the great social cost produced by the pursuit of tight monetary and fiscal policies. Most of the Italian left would share the view that only if EMU is constructed will Europe have the power to assert its potential social model of postmodernity against the US neo-liberal version and whatever model it is that the Asian tigers represent. In other words, it is only by accepting a heavy dose of neoliberalism now that there might be protection from it later.

\section{The new shape of the right}

The collapse of Christian democracy in a wave of scandals has of course been a blow for the Catholic Church in its home territory, but when the 1996 elections saw new Catholic parties on both sides of the new national political divide the church happily announced that there were now Catholic groups throughout the system, 
which was a better guarantee of the church's influence. If there is a neo-liberal Vatican somewhere in Wall Street it is probably saying the same. While there is a neo-liberal component in the Government, there is of course a much larger one in the opposition, in Forza Italia. Berlusconi's party is often credited with little political programme other than the defence of its leader and his associates from investigation by Mani pulite and the protection of his right to own three national television channels. It has, however, also proved itself to be the rallying point for most neo-liberal forces in the country. Berlusconi lists Margaret Thatcher as his main political inspiration; when his dubious coalition including fascists was elected in 1995 that lady made enthusiastic noises, and the British Government, the most neo-liberal in Europe, was the only one to offer warm felicitations.

Although it is easy to depict FI as a political freak, it has a fair claim to be something more prototypical: the world's first truly postmodernist political party. Its power base is entirely in the key growth centres of the postindustrial economy: financial services, downmarket television stations and newspapers, one of the world's greatest football teams, a supermarket chain, condominium apartment blocks. As a political organisation it does not really bother with anachronistic things like members and local structures; its money comes from the firms it owns, not from footling membership donations and jumble sale proceeds. To the extent that it needs people on the ground, it can deploy employees of the firms from which it derives; instead of fighting to win the attention of the media, it simply pumps out its material through its own television stations. Few modern party leaders could lay hand on heart and deny that they might prefer a structure of this kind to the assemblages of inconvenient and disobedient enthusiasts and penniless groups which are their inheritance from the early twentieth century.

When FI temporarily took up the reins of government in 1994, both its own leaders and everyone else proclaimed the end of the First Italian Republic and the dawn of a totally new politics. The claim proved as fatuous as Newt Gingrich's claim to have unleashed a second American revolution in 1994, or that of the short-lived Social Democratic Party in Britain in the early 1980s to have initiated a new politics when in fact it was the only force defending the decaying postwar consensus. In the case of Forza Italia it was another case of Lampedusa's 'Se vogliamo che tutto rimanga come è, bisogna che tutto cambi' (Il Gattopardo, 1957). This is usually translated as 'If we want things to stay as they are, things will have to change.' In fact it means, far more preposterously: 'If we want everything to stay as it is, everything will have to change.' It can only be understood in the context described above of a political class cut off from and contemptuous of its public. By creating such an illusion of total change that people lose their bearings, the rulers will be able to ensure that nothing of what is essential to them really changes. The Berlusconi financial conglomerate grew up in the corrupt atmosphere of the 1980s and depended for a good deal of its activities on political concessions. The whole political system had to be seen to change so that a nation sick of corruption could feel that everything had been made new, while the core political practices of the period could be protected and sustained.

It is an interesting fact that nowhere in the world does neo-liberalism survive as a political force in its own right, despite the apparent attraction of its message of low taxes and individual consumer liberty. This is true even in the United States, where the Republican Party has to add massive infusions of patriotism, fundamentalist Christianity and appeals 
to family values to the basic economic message. In the UK, too, neo-liberalism ties itself to hostility to the European Union and other vaguely nationalist sentiments. Something very similar happened to original liberalism when it faced the mass electorates of the twentieth century. A political message which concentrates on individuals and their rights, which is what unites all forms of liberalism, is almost by definition incapable of establishing the stable collective identities and loyalties on which all politicians desire to build their power, however much they also want and need to attract additional, more instrumental votes.

Italian neo-liberalism within the present opposition has two such collective components. First there is the vaguely nationalist symbolism of FI itself: its symbol is the Italian tricolour; its very name a national football cry. Rather more substantive is the role within the reformulated right of Alleanza Nazionale, the openly nationalistic successor to the postwar Movimento sociale Italiano (MSI), which was itself the successor of Mussolini's Fascist Party. The present leaders of AN deny that they are fascist, though they openly revere Mussolini's achievements and at local level their activists engage in the occasional beatings of leftwing students, gypsies and inconvenient minorities that characterised the squadristi of the 1920s. At the same time it must be remembered that AN represents many of the dispossessed of the Mezzogiorno. Like the Communists, the fascists of MSI had been largely excluded from the politicians' gravy train of the postwar republic. They may yet find a means to represent these people with something other than promises of subventions that never reach them.

The association between neo-liberalism and fascism is as vulnerable to internal contradictions as that among former
Communists, Catholics and neo-liberals: much of the feeling of insecurity and loss of control over international economic forces that leads people to embrace fascism is the direct consequence of neoliberal policies. If the logic of this leads to the advocacy of nationalist protectionism the coalition can be broken open, as Pat Buchanan's bid for the presidential nomination almost did to the US Republican Party. Provided this can be avoided, however, and nationalism can content itself with identifying ethnic minorities or organisations like the UN or the EU as the enemy, the two forces can coexist very happily. Nationalism provides the source of passionate identity that the rather bloodless doctrine of neo-liberalism lacks; while in exchange neo-liberalism can provide the best badge of political respectability available at the fin de siècle for a movement which, on the basis of its performance for most of the century, had put itself irredeemably beyond the pale.

\section{Conclusion}

Much about the Italian political scene seems remote from the preoccupations of Britain or other northern European societies. However, we might all gain from examining whether the dimension of the personal and the community might illuminate our routine confrontations between individual and collective. Also, Italy is not so odd in bringing together, even if only temporarily, an array of parties and shattered fragments of former parties to produce a confrontation between, on the one side, socialism, Christianity and an element of neo-liberalism, and, on the other, neo-liberalism and nationalism. This is not only fundamentally understandable, but very similar to what the UK is currently doing with just two parties. 